\title{
ARTIGO
}

do https://doi.org/10.22481/praxisedu.v16i37.6174

\section{EDUCATION AND UPBRINGING THROUGH SOCIALIZATION OF EVERY CHILD OF THE ARCTIC INDIGENOUS PEOPLES IN THE GLOBAL MODERN SOCIETY}

\author{
EDUCACIÓN Y CRIANZA A TRAVÉS DE LA SOCIALIZACIÓN DE TODOS LOS
} NIÑOS DE LOS PUEBLOS INDÍGENAS DEL ÁRTICO EN LA SOCIEDAD MODERNA MUNDIAL

\author{
EDUCAÇÃO E EDUCAÇÃO PELA SOCIALIZAÇÃO DE TODAS AS CRIANÇAS DOS \\ POVOS INDÍGENAS DO ÁRTICO NA SOCIEDADE MODERNA GLOBAL
}

Zoya Semyonovna Zhirkova

North-Eastern Federal University - Rússia

Dmitry Alekseevich Danilov

North-Eastern Federal University - Rússia

Tatyana Vasilievna Tretyakova

North-Eastern Federal University - Rússia

Antonina Afanasyevna Vinokurova

Institute of Languages and Culture of the North-East of the Russian Federation - Rússia

\section{Evdokia Pavlovna Yakovleva}

North-Eastern Federal University - Rússia

\begin{abstract}
At present, Russia is experiencing a revival of national cultures, traditions, and spiritual foundations of its peoples. This determines a growing interest in the issues of education, upbringing and development of a person who is aware of the main norms and values of their people, society and country, has a rich ethnocultural background, a developed identity in the multicultural environment, and a respectful attitude to different cultural values of other peoples that are unique and original. These problems can be solved by means of education. The research goal of this study was to propose and justify the theoretical and methodological foundations for the development of a regional educational space using the pedagogical potential of ethnocultural traditions in the system of education and upbringing through the socialization of every child of the Arctic indigenous peoples. The research objectives are: to solve the problem of upbringing and education through ethnocultural traditions, and to identify ways and forms of their implementation through the socialization of the indigenous peoples
\end{abstract}


of the Arctic. The problems of the formation of the Arctic indigenous peoples were studied with cultural, civilizational, synergetic, and interdisciplinary methodological approaches, which enabled the authors to comprehensively explore the phenomenon of the circumpolar (Arctic) civilization, to substantiate the need to increase the role of the ethnocultural component in the socialization, education and upbringing of the youth of the indigenous (nomadic) peoples of the North in modern conditions of globalization, and to highlight its pedagogical potential. The following methods were used: field research, interviews, observations, and testing. The study involved 305 third and fourth graders in rural educational institutions; 76 of them studied in nomadic schools. The results of the study demonstrated positive dynamics. Qualitative data obtained during the interviews or observation can be used as the basis for selecting units or indicators when creating other research tools aimed at obtaining quantitative data. The theoretical and practical significance of the study is determined by the fact that its conclusions and provisions can be used for practical realization of the potential of the ethnocultural traditions of the Arctic indigenous peoples.

Keywords: Upbringing; Education; Civilization; Socialization.

Resumen: En la actualidad, Rusia está experimentando un renacimiento de las culturas nacionales, las tradiciones y los fundamentos espirituales de sus pueblos. Esto determina un interés creciente en las cuestiones de educación, crianza y desarrollo de una persona que es consciente de las principales normas y valores de su pueblo, sociedad y país, tiene un rico bagaje etnocultural, una identidad desarrollada en el entorno multicultural y una actitud respetuosa hacia los diferentes valores culturales de otros pueblos que son únicos y originales. Estos problemas pueden ser resueltos por medio de la educación. El objetivo de la investigación fue proponer y justificar los fundamentos teóricos y metodológicos para el desarrollo de un espacio educativo regional utilizando el potencial pedagógico de las tradiciones etnoculturales en el sistema de educación y crianza a través de la socialización de cada niño de los pueblos indígenas del Ártico. Los objetivos de la investigación son: resolver el problema de la crianza y la educación a través de las tradiciones etnoculturales, e identificar las formas y maneras de su aplicación a través de la socialización de los pueblos indígenas del Ártico. Los problemas de la formación de los pueblos indígenas del Ártico se estudiaron con enfoques metodológicos culturales, de civilización, sinérgicos e interdisciplinarios, que permitieron a los autores explorar ampliamente el fenómeno de la civilización circumpolar (ártica), para fundamentar la necesidad de aumentar el papel del componente etnocultural en la socialización, la educación y la crianza de la juventud de los pueblos indígenas (nómadas) del Norte en las condiciones modernas de la globalización, y para poner de relieve su potencial pedagógico. Se utilizaron los siguientes métodos: investigación de campo, entrevistas, observaciones y pruebas. En el estudio participaron 305 alumnos de tercer y cuarto grado de instituciones educativas rurales; 76 de ellos estudiaron en escuelas nómadas. Los resultados del estudio demostraron una dinámica positiva. Los datos cualitativos obtenidos durante las entrevistas u observaciones pueden utilizarse como base para seleccionar unidades o indicadores al crear otros instrumentos de investigación destinados a obtener datos cuantitativos. La importancia teórica y práctica del estudio está determinada por el hecho de que sus conclusiones y disposiciones pueden utilizarse para la realización práctica del potencial de las tradiciones etnoculturales de los pueblos indígenas del Ártico.

Palabras clave: Crianza; Educación; Civilización; Socialización.

Resumo: Atualmente, a Rússia está experimentando um renascimento das culturas nacionais, tradições e fundamentos espirituais de seus povos. Isto determina um interesse crescente nas questões de educação, educação e desenvolvimento de uma pessoa que está consciente das principais normas e valores do seu povo, sociedade e país, tem um rico background etnocultural, uma identidade desenvolvida no ambiente multicultural, e uma atitude respeitosa aos diferentes valores culturais de outros povos que são únicos e originais. Estes problemas podem ser resolvidos por meio da educação. $\mathrm{O}$ objetivo da pesquisa foi propor e justificar os fundamentos teóricos e metodológicos para o desenvolvimento de um espaço educativo regional utilizando o potencial pedagógico das tradições 
etnoculturais no sistema educativo e de educação através da socialização de cada criança dos povos indígenas do Ártico. Os objetivos da pesquisa são: resolver o problema da criação e educação através das tradições etnoculturais, e identificar formas e formas de sua implementação através da socialização dos povos indígenas do Ártico. Os problemas da formação dos povos indígenas do Ártico foram estudados com abordagens metodológicas culturais, civilizacionais, sinergéticas e interdisciplinares, que permitiram aos autores explorar de forma abrangente o fenômeno da civilização circumpolar (Ártico), para fundamentar a necessidade de aumentar o papel do componente etnocultural na socialização, educação e formação da juventude dos povos indígenas (nômades) do Norte nas condições modernas da globalização, e para destacar seu potencial pedagógico. Foram utilizados os seguintes métodos: pesquisa de campo, entrevistas, observações e testes. O estudo envolveu 305 alunos da terceira e quarta séries em instituições de ensino rural; 76 deles estudaram em escolas nômades. Os resultados do estudo demonstraram uma dinâmica positiva. Os dados qualitativos obtidos durante as entrevistas ou observações podem ser usados como base para a seleção de unidades ou indicadores quando da criação de outras ferramentas de pesquisa com o objetivo de obter dados quantitativos. O significado teórico e prático do estudo é determinado pelo fato de que suas conclusões e disposições podem ser utilizadas para a realização prática do potencial das tradições etnoculturais dos povos indígenas do Ártico.

Palavras-chave: Criação; Educação; Civilização; Socialização.

\section{Introduction}

Recently, modern global society has experienced significant changes that have influenced the socio-economic policy of the state and all aspects of the educational system, since education as part of the sociocultural infrastructure is directly connected with the economic and socio-political development of the country.

Education has been and remains the basis of culture and is defined as a specific area of the social policy of a region that determines the development perspective for other areas of the region's life (Zeibote, Volkova \& Todorov, 2019; Ismail et al., 2019). The educational system is to preserve and develop the cultural traditions and specifics of the region that grant students access to the historical, cultural, ethnographic, moral, and other aspects of heritage of the inhabitants of the territory. Along with maintaining the country's common educational space, regions should be able to form their own mechanisms for self-development and stimulation of innovative processes in the field of education (Volchik \& Maslyukova, 2019). In these conditions, it is especially relevant to develop an educational concept that would ensure the continuity of the unique "philosophy" of children's education and upbringing based on the original culture of the peoples of the Arctic, and, at the same time, to make it fully compliant with modern requirements.

Researchers have proposed the foundations for the development of the northern national schools (Vinokurova, Dannemark \& Todal, 2016), the Even national school (Robbek, 
2007), social and pedagogical conditions for improving the advanced literary native (Even) language, and the innovative project "Network Interaction of Topilinskaya Secondary School and Ailik Nomadic School" (Zhirkova, 2017), which laid the special principles of education and upbringing of children of the indigenous peoples of the North. Having analyzed the existing practices, we came to the conclusion that the emphasis should be placed on the education and upbringing of a creative person who is ready to transform the world, along with increased cultural and linguistic consciousness as the basis for preservation and development of national and cultural identity (self-identification).

\section{Literature Review}

The analysis of the research papers of international and Russian scientists showed that the ethnocultural traditions of the Arctic peoples are an especially relevant area in the global modern society.

The scientific discovery of the phenomenon of the Arctic circumpolar civilization initiates the discussion about new prospects for the application of traditional knowledge of the ancestral culture and lifestyle of the indigenous peoples of the Arctic. This knowledge may also be applied to find a solution to the civilizational crisis with a focus on global sustainable development. This is confirmed by a position that has recently emerged in international and Russian science that considers the special place and role of these peoples in the development of mankind (Fondahl, Filippova \& Mack, 2015; Heininen, 2015; Koptseva \& Kirko, 2015; Krupnov, 2003; Lukin, 2012; Robbek, 2007; Yakovets \& Rastvortsev, 2017).

According to the researchers, this implies the need for preservation and dissemination of the values of the Arctic civilization in the scientific, educational, informational, and geopolitical aspects of the dialogue of modern civilizations.

In this study, we relied on the ideas about pluralism and criticism (Cars \& West, 2015; Öhman, 2006), the achievements and best practices in education aimed at sustainable development of society, as well as the papers (Tevlina \& Soleim, 2019) analyzing the relationship between historical, linguistic and cultural knowledge of the Arctic and a person's belonging to a certain ethnic and socio-cultural group. The historically established set of rights of indigenous peoples in the field of education has been explored by Dannemark and others (2015) and Dannemark (2015). Other researchers (Altbach \& Knight, 2007; Piven \& Pak, 2006) studied the Bologna process and how the internationalization of higher education, motivation 
and reality influence the educational process and outcomes. In addition to this, we examined the analytical findings (Malakhova, Kirko \& Yanova, 2018; Kopnina, 2013) related to the economic socialization of high school students in the Far North and the implications of environmental education, and the attitude of Dutch children to consumption.

In addition to this, a number of researchers, e.g., Danilov (2016), has contributed to the study of organizational and pedagogical conditions in the rural schools of Yakutia. The researcher in his work highlights the unique nature of the cultural space of the region, the importance of the Arctic both for the economy and ecology, and for the national and cultural development of the state: Russia's national interests are connected with exploration of the region's natural resources, preserving the environment, and maintaining the lifestyle and culture of the Arctic peoples.

Despite the intensive research conducted by teachers in this area, some issues still require further study. They are the role of the national circumpolar approach in creating a regional space in the territory beyond the Arctic Circle or in the Arctic inhabited by the indigenous peoples (Kefeli, 2013), the concept of the circumpolar world proposed by Gumilev (1988) and Seroshevsky (1993), as well as the pedagogical potential of the ethnocultural traditions of the nomadic peoples of the North in the development and formation of the regional educational space in the Arctic. The main goal of the study is to consider the unique opportunities of the circumpolar civilization that would ensure the creation of the circumpolar educational space in the Republic of Sakha (Yakutia), its role and prospects regarding socialization, education and upbringing of the youth based on the maximum use of the pedagogical potential of ethnocultural traditions of the peoples of the North reflecting the specifics of their social environment, lifestyle, traditional occupations, spirituality, values, norms, and rules of conduct.

The study was mainly carried out in rural schools, the most significant form of education for the indigenous peoples of the North. These institutions experienced in the past and are still facing all the drawbacks associated with the development of rural schools in Russia as a whole and in Yakutia in particular. Currently, more than $30 \%$ of Russians live in the countryside, which preserves the traditions of folk culture.

\section{Materials and Methods}

To accumulate and interpret the research results, we used effective data collection tools 
that meet the requirements for the quality of measurements and were adapted to the psychological characteristics of the children of the Arctic peoples and the natural economic conditions of the region.

Let us consider the criteria for the research into rural schools of the Far North in the control and experimental groups.

We examined and analyzed the practices of primary school teachers related to the formation and development of cognitive interests, as well as the conditions for achieving positive results that contribute to their development and activation. The following criteria were applied to assess the activities of primary school teachers aimed at developing students' personalities in a lesson (Dannemark et al., 2017; Costello, Wachtel \& Wachtel, 2009; Ivars et al., 2018; Penttila, 2015). The quality of the educational process was evaluated regarding:

- Clarity of the organization.

- Compliance of the main parameters with norms and standards.

- Accessibility of goals. Children's inner acceptance of the goal of the upcoming work - that is, their understanding why this should be done, and what result is expected.

- Stability and accuracy of the basic processes and actions of students and teachers.

- Clarity of plans, programs, and schedules implementation, and socio-psychological comfort.

- Safety of workload for students' health.

The work of primary school teachers in rural schools of the Republic of Sakha (Yakutia) was assessed according to the adapted questionnaires developed by Sevruk and Yunina (2003).

\section{Results}

Primary school teachers of the areas of Verkhoyansk (94), Oymyakonsky (84), and Momsky (63) were asked to assess the lesson's quality. Table 1 shows the survey results - the percentage in the control and experimental groups.

Table 1. The analysis of the work of primary school teachers in rural schools (the sample consisted of 78 teachers) 


\begin{tabular}{|c|c|c|}
\hline Survey items & $\begin{array}{l}\text { Control group of primary } \\
\text { school teachers in rural } \\
\text { schools }\end{array}$ & $\begin{array}{l}\text { Experimental } \\
\text { group of primary } \\
\text { school teachers }\end{array}$ \\
\hline $\begin{array}{c}\text { 1. Proficient knowledge of subject } \\
\text { matter }\end{array}$ & $100 \%$ & $100 \%$ \\
\hline $\begin{array}{l}\text { 2. Correct, accurate, emotional, and } \\
\text { educated speech }\end{array}$ & $100 \%$ & $100 \%$ \\
\hline 3. Establishes intersubject links & $81 \%$ & $93 \%$ \\
\hline 4. Uses a) social experience & $87 \%$ & $92 \%$ \\
\hline 5. b) visual aids & $85 \%$ & $88 \%$ \\
\hline 6. c) dynamic didactic materials & $76 \%$ & $99 \%$ \\
\hline $\begin{array}{l}\text { 7. Varies the difficulty of home } \\
\text { assignments (state standard, school, } \\
\text { or individual) }\end{array}$ & $74 \%$ & $91 \%$ \\
\hline $\begin{array}{l}\text { 8. Encourages substantiating and } \\
\text { giving reasons for the answers, as } \\
\text { well as using facts from other areas } \\
\text { of knowledge }\end{array}$ & $98 \%$ & $99 \%$ \\
\hline $\begin{array}{l}\text { 9. Encourages a) learners' initiative } \\
\text { and autonomy }\end{array}$ & $98 \%$ & $100 \%$ \\
\hline b) individual learning achievements & $97 \%$ & $99 \%$ \\
\hline $\begin{array}{l}\text { 10. Gives tasks that develop } \\
\text { intuition, creative imagination, and } \\
\text { emotional and sensory perception }\end{array}$ & $88 \%$ & $97 \%$ \\
\hline $\begin{array}{l}\text { 11. Pays attention to the quality of } \\
\text { students' speech }\end{array}$ & $96 \%$ & $98 \%$ \\
\hline $\begin{array}{l}\text { 12. Uses the following educational } \\
\text { techniques: } \\
\text { a) differentiated and individualized } \\
\text { learning }\end{array}$ & $21 \%$ & $35 \%$ \\
\hline b) problem-based learning & $15 \%$ & $37 \%$ \\
\hline c) team thinking activities & $9 \%$ & $21 \%$ \\
\hline d) dialogue learning & $10 \%$ & $22 \%$ \\
\hline e) reflexive learning & $14 \%$ & $29 \%$ \\
\hline f) project-based learning & $10 \%$ & $33 \%$ \\
\hline g) health-saving techniques & $21 \%$ & $44 \%$ \\
\hline
\end{tabular}

The diagnostic results presented in Table 1 allowed us to draw the following conclusions. The teachers of the experimental group enhanced students' cognitive activity with 
teaching methods and appropriate educational content, which stimulated students' selfdevelopment. The main unit of the educational content in developmental education is the concept, which is mastered through subject-transformative actions of students.

The survey results showed that teachers widely use dynamic didactic materials. In lessons, they effectively applied the techniques of dialogue learning and initiated interesting discussions with active participation of students. Dialogue is considered as a technology of the subject-subject relationships, an instant feedback, reflexive mastering of one of the dialogue types - between the student and their inner self. At present, teachers more actively adopt the project-based method, which includes a combination of research, search, and problem-based methods, all of which imply creativity. For initiating team thinking, teachers used different techniques that were aimed at the effective processing of the information received and its faster transition to conscious knowledge.

Thus, a survey of the work of primary school teachers in the Arctic rural schools showed that all the components of the educational process were aimed at the result, at solving the educational, upbringing, developing, practical goal of teaching, as well as different aspects of activity: intellectual, personal, and social ones.

The conducted survey involved experts, primary school teachers, and the administration of rural schools and was conducted to assess the intensity of cognitive activity with the test developed by Gorchinskaya (2015) "Cognitive activity of a primary school student". The standardized questionnaire form included five multiple choice questions.

Table 2. Indicators of the intensity of cognitive activity of primary school students

\begin{tabular}{|c|c|c|c|c|}
\hline Groups & $\begin{array}{c}\text { Students, } \\
\text { total }\end{array}$ & $\begin{array}{c}\text { Strong } \\
\text { cognitive } \\
\text { activity }\end{array}$ & $\begin{array}{c}\text { Moderate } \\
\text { cognitive } \\
\text { activity }\end{array}$ & $\begin{array}{c}\text { Weak } \\
\text { cognitive } \\
\text { activity }\end{array}$ \\
\hline Initial testing & 241 & $89-37 \%$ & $142-58.5 \%$ & $11-4.6 \%$ \\
\hline Control group & 120 & $41-34.1 \%$ & $72-60 \%$ & $7-5.8 \%$ \\
\hline Experimental group & 120 & $48-40 \%$ & $68-56.6 .8 \%$ & $4-3.3 \%$ \\
\hline
\end{tabular}

The table data demonstrate that in the control group 37\% of the students had strong cognitive activity, $58.5 \%$ had moderate cognitive activity, and $4.6 \%$ had weak cognitive activity. 
The results indicate positive changes in the intensity of students' cognitive interest: the share of those with strong cognitive activity increased to $40 \%$, those with moderate cognitive activity stayed steady around $57 \%$, and the share of students with weak cognitive activity decreased by $3 \%$.

Thus, having studied the characteristics of learning motivation, cognitive interest, and cognitive activity of primary school students, we identified a higher level of intellectual skills related to information processing, development of students' actions. We studied their practical, conscious, and self-control aspects, the ability to have a consistent assessment of their actions and to support their assumptions.

The results were assessed with different methods: tests, presentations of students' creative works (the topics were chosen by the students themselves), drawings, portfolios, the pedagogical method of "Fantastic Binomial" by Rodari (2011), tests to identify the level of sociability and general knowledge, clarifying conversations with students, teachers, and parents. Table 3 summarizes the results of the study.

Table 3. Independent creative works

\begin{tabular}{|c|c|c|}
\hline Levels & $\begin{array}{c}\text { Free composition } \\
\text { Control group/experimental group } \\
\text { in rural schools (total: 229) }\end{array}$ & $\begin{array}{c}\text { Free composition in } \\
\text { nomadic schools } \\
\text { (total: } 76)\end{array}$ \\
\hline Creative & $38 / 57$ & $12 / 18$ \\
\hline Advanced & $78 / 93$ & $21 / 31$ \\
\hline Basic & $102 / 73$ & $38 / 23$ \\
\hline Low (critical) & $11 / 6$ & $6 / 4$ \\
\hline
\end{tabular}

The survey involved 305 third and fourth graders in rural schools, of which 76 were students of nomadic schools. Assessing the level of their creative works, the experts set the following criteria: the creative level -- reflecting the independent use of knowledge obtained from various sources, planning, independent hypothesizing, clearly visible positive attitude of the student, and ability to undertake independent reflection; the advanced level-finding the required information, analyzing it, applying knowledge gained independently from a textbook or other sources recommended by the teacher, hypothesizing with the help of the teacher or others, and ability to undertake reflection; the basic level-choosing from the provided information sources, using a goal and planning activities proposed by the teacher, independent 
work according to the plan given by the teacher or somebody else, reflection with the teacher's help; the critical level-low psychological readiness for independent, creative work, a superficial presentation of the material that does not reveal the students' attitude towards it, and activity of the reproductive type.

We checked the following independent creative works in the Russian language: students could choose among the topics of "My family," "Our native village," "The reindeer is the beauty and pride of the North," "My Homeland," "Parents' Activities," and "My native language."

The students of nomadic schools chose such topics as "The reindeer is the beauty and pride of the North" and "My family." The students' works assessed as creative demonstrated a holistic view on the family, a detailed description of the parents, including character, determination, attitude toward other people, relatives, love for deer, nature, their strengths, weaknesses, and a desire to be somewhat similar to them. The students wrote about the work of reindeer herders, emphasizing that their life and nature are interconnected. The students were proud of their family and values. The experts, assessing the works, noted that the students of nomadic schools had developed observation skills, especially related to the life of plants and animals of the region and demonstrated a vivid emotional and evaluative attitude toward the described phenomena.

\section{Discussion}

Having analyzed the research papers, we showed that the methodological approaches used in this study differ from those characteristic of ethnographic and pedagogical research. The applied hermeneutic method made it possible to reveal the meaning and significance of the components of ethnopedagogy. Ethnopedagogy was considered not only a way of transferring knowledge and skills, but also a process and result of the nation's cognitive activity. Such an approach allowed Russian ethnographic scholars to go beyond the studied issues and to consider the development of ethnopedagogy through the development of the ethnos, with a focus on the structure of folk pedagogy (Volkov, 2011; Nezdemkovskaya, 2009, Khakimov, 2003).

We described the conditions stimulating the development of students' cognitive interest. Interest is a form of manifestation of cognitive needs, which help the individual become aware of the goals of their activity. Cognitive interest is the quality of the individual that is the 
most important motive for learning, which is developed through educational content, methods and forms, the style of activity, atmosphere, and psychological climate of the team.

The developed cognitive interest of students:

- activates not only cognitive processes of students, but also their creative efforts in various fields;

- ensures a greater concentration of goals and activity methods, stimulates the search for new ones, expands and deepens students' knowledge in the subject area, as well as in more general areas (about the world, mankind, and a person himself), which encourages self-knowledge;

- brings a kind of emotional satisfaction, increasing one's motivation to do a certain activity for a long period of time; the formation and development of cognitive interests by teachers with a focus on the activity component of education will ensure the continuity of goals in general education.

Writing creative works contributes to the development of interests, the intellectual growth of students, pride in overcoming difficulties, and most importantly, gives them confidence in their own strengths and promotes further self-improvement. Here one should mention the position of psychologists Ribot (1906) and Meili (1972) who believe that the development of creative abilities requires the improvement of both logical and figurative thinking. It is known that all abilities develop in this activity.

\section{Conclusion}

The phenomenon of "circumpolar civilization" implies a change in the role of the national component by expanding its ethnocultural content in the education, upbringing, and socialization of the youth. It underlies the northerner's personality, whose worldview and behavior are guided by both modern requirements of society to the citizen and patriot and traditional forms of interaction between nature and people. This person identifies themselves as an organic component of the natural environment of the North, a resident of the Arctic region and part of a unique ethnic community, a carrier and successor of the national traditions of the Arctic peoples. The education system, which fully reflects the potential of ethnocultural traditions, in turn, has an impact on all the resources of the region, maintaining and creating potential for further development of unique ethnic groups of the northern peoples. 
In this research, we identified and described the ethnocultural component of the content of education and upbringing in the circumpolar educational space of the nomadic peoples of the North that would lead to the changes in:

- the content and structure of the learning process in educational organizations throughout the region in the emerging educational network.

- the ratio of basic and additional education (training in a nomadic school, the active use of family and tribal education).

- the role of parents in the educational process (a parent-tutor conducting ethnocultural educational work with children and schoolchildren).

- management forms (state or public: community-based, parental, and local councils).

- innovative forms and means in upbringing and education based on ethnocultural traditions: family, tribal, community education, and national educational activities.

- the teachers training and retraining system.

It was shown that, in the global modern society, the system of education and upbringing should contribute to the socialization of every child of the indigenous peoples of the Arctic.

\section{Acknowledgments}

The research results were published with the support of the RFBR grant No. 17-0618020 as part of the scientific and pedagogical expedition "The influence of ethnocultural traditions of nomadic peoples on the development of student's personality."

\section{REFERENCES}

1. Altbach, G., \& Knight, J. (2007). The Internationalization of Higher Education: Motivation and Realities. Journal of Studies in International Education, 11(3/4), 290-305.

2. Cars, M., \& West, E.E. (2015). Education for Sustainable Society: Attainments and Good Practices in Sweden during the United Nations Decade for Education for Sustainable Development (UNDESD). Environment, Development and Sustainability, 17(1), 1-21.

3. Costello, B., Wachtel, J., \& Wachtel, T. (2009). The Restorative Practices Handbook for Teachers, Disciplinarians and Administrators (Building a Culture of Community in Schools). Bethlehem, Pennsylvania: International Institute for Restorative Practices. 
4. Danilov, D.A. (2016). Updating Education in the Context of Global Transformations. Cheboksary: Center for Scientific Cooperation "Interactive Plus".

5. Dannemark, N. (2015). Språk I Guovdageaidnu. The Arctic 21st Century. Humanitarian Sciences, 3(6), 60-76.

6. Dannemark, N., Logje, M.R., Siri, K.M., Syrovatskaya, A., \& Todal, J.J. (2015). Undervisninga i samisk som førstespråk i noreg eit historisk tilbakeblikk. The Arctic 21st Century. Humanitarian Sciences, 3(6), 52-60.

7. Dannemark, N., Logje, M.R., Siri, K.M., Syrovatskaya, A., Todal, J.J., \& Vinokurova, A. (2017). Indigenous Languages of the North: A Comparative Analysis of the Language Situations in Topolinoe in Sakha and Guovdgeaidnu in Sápmi. WINHEC: International Journal of Indigenous Education Scholarship, 1, 57-81.

8. Fondahl, G., Filippova, V., \& Mack, L. (2015). Indigenous Peoples in the New Arctic. B. Evengård, L.J. Nymand, \& Ø. Paasche (Eds.), The New Arctic (pp. 7-22). Cham: Springer.

9. Gorchinskaya, A.A. (2015). Cognitive activity of a primary school student. https://infourok.ru/programmi-nablyudeniya-viyavleniya-interesov-shkolnikov-knauchnopoznavatelnoy-deyatelnosti-3222495.html

10.Gumilev, L.N. (1988). Ethnic Groups in Landscapes. Man and Nature, 10, 78-89.

11.Heininen, L. (2015). The Arctic Region as a Space for Trans-disciplinary, Resilience and Peace. Arctic and North, 4(21), 26-33.

12.Ismail, R., Gopalasamy, R.C., Saputra, J., \& Puteh, N. (2019). Impacts of a Colonial Policy Legacy on Indigenous Livelihoods in Peninsular Malaysia. Journal of Southwest Jiaotong University, 54(5). http://jsju.org/index.php/journal/article/view/368

13. Ivars, P., Fernandez-Verdu, C., Llinares, S., \& Choy, B.H. (2018). Enhancing Noticing: Using A Hypothetical Learning Trajectory to Improve Pre-Service Primary Teachers' Professional Discourse. EURASIA Journal of Mathematics, Science and Technology Education, 14(11), 1-16.

14. Kefeli, I.F. (2013). Circumpolar Civilization in the Geo-Civilization Structure of the Global World. Partnership of Civilizations, 4, 354-365.

15.Khakimov, E.R. (2003). Ethno-Psychology and Ethnopedagogy in the Pedagogical Process Design. Izhevsk.

16.Kopnina, H. (2013). An Exploratory Case Study of Dutch Children's Attitudes towards Consumption: Implications for Environmental Education. The Journal of Environmental Education, 44, 128-144.

17. Koptseva, N.P., \& Kirko, V.I. (2015). The Impact of Global Transformations on the Processes of Regional and Ethnic Identity of Indigenous Peoples Siberian Arctic. Mediterranean Journal of Social Sciences, 6(3), 217-224.

18. Krupnov, Yu.V. (2003). Northern Civilization. Academy of Trinitarianism. http://www.trinitas.ru/rus/doc/0012/001a/00120086.htm

19.Lukin, Yu.F. (2012). Arctic and Social Fears. Arctic and North, 5. http://www.arcticandnorth.ru/upload/iblock/c45/03.pdf

20. Malakhova, E.V., Kirko, V.I., and Yanova, M.G. (2018). Economic Socialization of Senior Schoolchildren in the Conditions of the Extreme North. Journal of Siberian Federal University. Humanities \& Social Sciences, 11, 1301-1314.

21.Meili, R. (1972). Basics of Personality Traits. Bern: Huber.

22.Nezdemkovskaya, G.V. (2009). Formation of Ethnopedagogics in Russia. Tomsk State University Journal, 326, 186-193.

23.Öhman, J. (2006). Pluralism and Criticism in Environmental Education and Education for Sustainable Development: A Practical Understanding. Environmental Education Research, 12, 149-163. 
24. Penttila, R.E.J. (2015). Student and Researcher Mobility in the European Arctic: Towards Growth in the North. https://www.uarctic.org/news/2015/6/student-and-researchermobility-in-the-european-arctic/

25.Piven, G., \& Pak, I.U. (2006). Higher Education in Kazakhstan and the Bologna Process. Russian Education \& Society, 48(10), 82-91.

26.Ribot, T. (1906). Essay on the Creative Imagination. Chicago, Illinois: Open Court Publishing Company.

27.Robbek, V.A. (2007). Scientific Bases of Education System Formation of Nomadic Peoples of the North. Novosibirsk: Nauka.

28.Rodari, G. (2011). Fantasy Grammar. Moscow: Samokat.

29.Seroshevsky, V.L. (1993). Yakuts: Experience in Ethnographic Research. Moscow.

30.Sevruk, A.I., \& Yunina, E.A. (2003). Monitoring the Quality of Teaching at School: A Guide for Teachers and Directors of Educational Institutions. Moscow: Pedagogical Community of the Russian Federation.

31. Tevlina, V.V., \& Soleim, M.N. (2019). A Large-Scale Meeting of Nordic and Russian Historians, Philologists and Archaeologists in the Arctic Norway. Arctic and North, 36, 143 150 .

32. Vinokurova, A.A., Dannemark, N., \& Todal, J. (2016). Indigenous Languages of the North - A Comparison of the Situation in Topolin in the Republic of Sakha (Yakutia) and Guovdageainu in Sapmi. Meridian, 3(3). http://meridian-journal.ru/site/article?id=250

33. Volchik, V., \& Maslyukova, E. (2019). Trust and Development of Education and Science. Entrepreneurship and Sustainability Issues, 6(3), 1244-1255.

34. Volkov, G.N. (2011). Pedagogy of Life. Cheboksary: Chuvash Publishing House.

35.Yakovets, Yu.V., \& Rastvortsev, E.E. (2017). The System of Long-Term Goals of Sustainable Development of Civilizations. Moscow: Institute of Economic Strategies.

36. Zeibote, Z., Volkova, T., \& Todorov, K. (2019). The Impact of Globalization on Regional Development and Competitiveness: Cases of Selected Regions. Insights into Regional Development, 1(1), 33-47.

37. Zhirkova, Z.S. (2017). Circumpolar Educational Space of the Region. St. Petersburg: Renome.

\section{SOBRE OS AUTORES:}

\section{Zoya Semyonovna Zhirkova}

North-Eastern Federal University, Pedagogical Institute, Department of Social Pedagogy, Yakutsk, 4/1 Kulakovskogo St., Russia, Postal Code: 677018.

Corresponding Author Email: zhirkovazoya@yandex.ru

(iD http://orcid.org/0000-0003-2815-7061

\section{Dmitry Alekseevich Danilov}


North-Eastern Federal University, Pedagogical Institute, Department of Social Pedagogy, Yakutsk, 3 Yaroslavskogo St., Russia, Postal Code: 677018.

Email: prof-danilov@mail.ru

(iD http://orcid.org/0000-0002-3590-1031

\section{Tatyana Vasilievna Tretyakova}

North-Eastern Federal University, Pedagogical Institute, Yakutsk, 6 Kurashova St., Russia, Postal Code: 677000.

Email: tatyana.v.tretyakova@yahoo.com

iD http://orcid.org/0000-0002-4391-5556

\section{Antonina Afanasyevna Vinokurova}

Institute of Languages and Culture of the North-East of the Russian Federation, Department of Northern Philology, Yakutsk, 202 Microrayon, bld. 25/2, Russia, Postal Code: 677000.

Email: vinokurova2007@yandex.ru

(iD http://orcid.org/0000-0003-0838-2958

\section{Evdokia Pavlovna Yakovleva}

North-Eastern Federal University, Department of Philosophy, Yakutsk, 3 Yaroslavskogo St., Russia, Postal Code: 677018.

Email: yakovleva45@inbox.ru

iD http://orcid.org/0000-0002-8967-7602

Recebido em: 08 de novembro de 2019

Aprovado em: 23 de novembro de 2019

Publicado em: 20 de janeiro de 2020 